\title{
PARADIGMAVÁLTÁS A RÓMAI UTAK KUTATÁSÁBAN? \\ A lelőhely-diagnosztika új lehetőségei az utak kutatásában Pannoniában
}

\section{BöDốCS AndrÁs ${ }^{1}$}

Magyar Régészet 9. évf. (2020), 3. szám, pp. 1-12. doi: https://doi.org/10.36245/mr.2020.3.2

A Római Birodalom közel ezeréves fennállása alatt az utak épitése, illetve helyreállitása állandóan központi kérdés volt, amely egyúttal mindig nagyszerü propagandaeszköznek is bizonyult. Sok helyen találkozhat a mai kor embere is ennek nyomaival: római mérföldkövek és egyéb épitoói tevékenység feliratai büszkén hirdetik az egykori remek, föleg katonai utász teljesitményeket.

\section{„MÉRFÖLDKÖVEK”}

A római utak kutatása is számontart anekdotába hajló felfedezéseket, melyek közül kétségtelenül az egyik legszórakoztatóbb az a történet, amely a francia idegenlégió egyik alakulatával és annak parancsnokával, vélhetően a nagy hírnevet szerzett Armand-Jacques Leroy de Saint-Arnaud tábornokkal esett meg, amikor 1850-ben Észak-Afrikában, az Atlasz-hegység egy addig járhatatlannak minősített szurdokán (egyes feltételezések szerint a Kanga-hágón) áttörte magát és csapatát. Azonban abbéli öröme, hogy ö az első a történelemben, aki azon a helyen átjutott, hamar eloszlott, amikor az egyik sziklafalban a legio III Augusta (Kr. u. 145-böl?) származó feliratát megpillantotta, amely tudatta az utókorral, hogy itt a legio katonái az utat kijavították (más vélemények szerint az utat megépítették: vON HAGEN, 1967; ÜröGDI, 1979; GLYNN-JONES, 1996, 121). Minden bizonnyal hasonlóan frenetikus élmény lehetett például az al-dunai római út és Tabula Traiana felirat első értő megtalálása is. Ezekhez hasonlót sajnos nemigen tudott Pannoniában a kutatás felmutatni. Ennek egyszerű okát Finály Gábor 1903-ban így fogalmazta meg: ,, Itt a Duna partján végigmenő természetes közlekedési vonalon kivül a dombvidék természete szerint a közlekedés lehetösége kevés helyen van kizárva.” (FinÁlY, 1903, 64). Ennek következtében a máshol évszázadokig egyetlen lehetőségként használt, látványos hegyi útszakaszok, sziklába vágott átjárók, ahol a római utászok megcsillogtathatták tudásukat, nem kerültek elő. Csak néhány példát említve: a donnasi sziklaút „alagútja” (1. kép), a svájci Pierre Pertuisnál található feliratos ,alagút” (CIL XIII, 5166) vagy a franciaországi Mont de Lans sziklába vágott átjárója a Bons felé vezető római úton (Chevallier, 1997; Moreno Gallo, 2004). A jól járható pannoniai terepen szinte bárhol lehettek a középkori közvetítéssel ránk maradt ókori forrásokból ismert római települések közötti útvonalak. Nemhiába, hogy a magyar régészeti kutatás szaklapjain több mint 150 éve vissza-visszatér időrőlidőre az a felkiáltás, amely az egykori római kori pannoniai úthálózat feltérképezésének lemaradására figyelmeztet, illetve annak szükségszerüségét sürgeti. Amire Rómer Flóris 1866-ban (RÓMER, 1866, 83) felhívja a figyelmet: „A római utak irányának meghatározása régi földleirásunkra nézve fölötte szükséges”, azt több mint 100 évvel később Tóth Endre kísértetiesen hasonlóan újra megfogalmazta

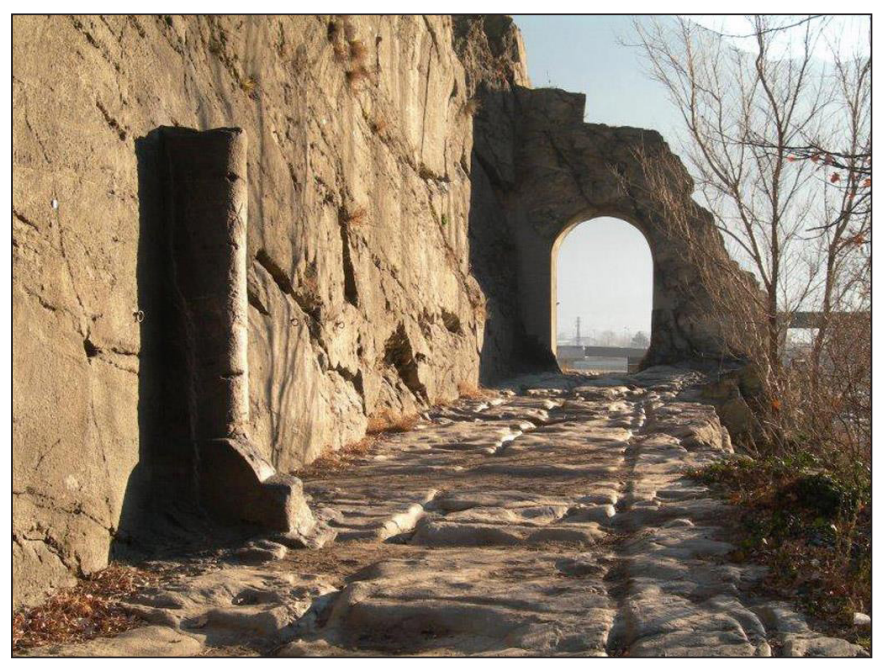

1. kép. Sziklafalba vágott római út mérföldkővel és átjáróval. Donnas, Aosta, Olaszország (kép forrása: http://www.crdl. scuole.vda.it/images/civilisation/paysage.pdf) 
Bödöcs András • Paradigmaváltás a római utak kutatásában?

(Tо́тн, 1975, 275). Az ezután eltelt évtizedben nagyobb fordulatot vett a római útkutatás, mint az előtte eltelt évszázad során, köszönhetően az archív térképi források újraértelmezésének, és azok modern, terepet értő régészeti összehasonlításának (TóTH, 1977; CSERMÉNYI \& TóTH, 1979-1980), valamint - más perspektívából: a földfelszíntől felemelkedve - útkutatási szempontból áttörést elérö légi régészeti kutatásoknak (VISY 1978; VISY 1980). Talán ezeket lehet a pannoniai római útkutatás tekintetében olyan „heuréka” pontoknak nevezni, amelyek megmutatták, hogy a sokáig kilátástalannak tünő helyzet ellenére lehetséges lehet az utak, úthálózat feltérképezése. Most, néhány évtizeddel később talán újra izgalmas fordulóponthoz jutottunk, a lehetőséget a régészeti térinformatika és a modern lelőhely-diagnosztika adta a kezünkbe.

\section{RÓMAI ÚTTERVEZÉS?}

A római úthálózat alapvetően különbözik a korábbi, őskori úthálózattól. A leginkább szembetűnő különbséget a tervezés és a kiterjedés jelenti - közel 100.000 km út épült ki a birodalom területén (Тótн, 2005). Bár az útépítés valószínúleg nem római találmány, hiszen a római köztudatban Hispaniai Isidorus szerint (Isid. Etim. 15, 16, 6) is úgy élt, hogy a kővel borított utak építését a rómaiak a főníciaiaktól - karthágóiaktól - tanulták, akik valószínüleg a félsivatagos területeken már kénytelenek voltak jobb minőségủ utakat létrehozni (Sмітн 1875, 1191-1195), de az a minőségü úthálózat, amely gyakran ma is a közlekedési útvonalak alapját képezi, egyértelmủen a római mérnöki tervezés vívmánya. Hugh Davies három fő szempontot tart a római úthálózat létrejöttének feltételeként (DAVIEs 2002, 16.):

1. Az egyik a topográfiai környezet ismerete és adaptálása a kezdő és kiinduló állomások között.

2. A második a közlekedés és azon belül inkább a szállítás fő szerepét hangsúlyozza.

3. A harmadik szempontot a mérnöki tudás jelenti, amelynek segítségével a természeti akadályokat leküzdik, és a topográfiai környezetet átalakítják.

A mérnöki - ezen belül is a földmérési - eljárások nehezen képzelhetők el megelőző tervezés nélkül. Ennek során a tervrajzok, a földrajzi környezet ismeretén alapuló tervezéskor pedig a felmérési vagy topográfiai térképek megléte nélkülözhetetlen. Nemcsak sokféle ókori, szakosodott földmérő mérnöki elnevezést ismerünk, de számos tervező és kivitelező eszközt is, amelyeket feltételezhetően az útépítésnél is felhasználtak (BöDőcs, 2008). Ugyanakkor jelenleg csak keveset tud a kutatás arról, hogy milyen módon és milyen vezérelv mentén határozhatták meg a nyomvonalat, mert olyan „kézikönyvjellegü” útmutató nem áll rendelkezésünkre, amely az útépítés módszereiről Vitruvius építészeti munkájához hasonló módon részletesen beszámolna erről. A technológiai fortélyokról Vitruvius munkája (Vitr. 5, 1; Tíz könyv az építészetről), illetve Statiusnak (Stat. silv. 4, 3) a via Domitia építéséröl írt verse alapján alkothattunk a régészeti adatokon kívül képet. Ezek azonban legfeljebb a „hogyan” kérdésre adnak némi választ, a „miért pont ott” kérdést nem tárgyalják. Az említett két forráshelyen kívül néhány törvényszöveg említ meg néhány részletet, mint például azt, milyen szélesek legyenek az utak. Csupán egy forráscsoport szól a tervezés sajátosságairól, egy olyan speciális gyűjtemény, amelyet többé-kevésbé antik földmérő szakemberek jegyeztek le. Ezt a forrásgyüjteményt nevezzük Corpus Agrimensorum Romanorum (CAR)-nak. Az itt olvasható leírások olyan úthálózatrendszer létesítésének problematikáját járják körül, ami a késő köztársaság, illetve a kora császárság idején kialakult módszer szerint a veteranusok földhöz juttatásakor kialakított, szigorú ortogonális birtokrendszer határoló útjait érinti (2. kép). A fentebb említett törvényszövegekben említett paraméterek is legtöbbször ilyen utakról rendelkeznek,

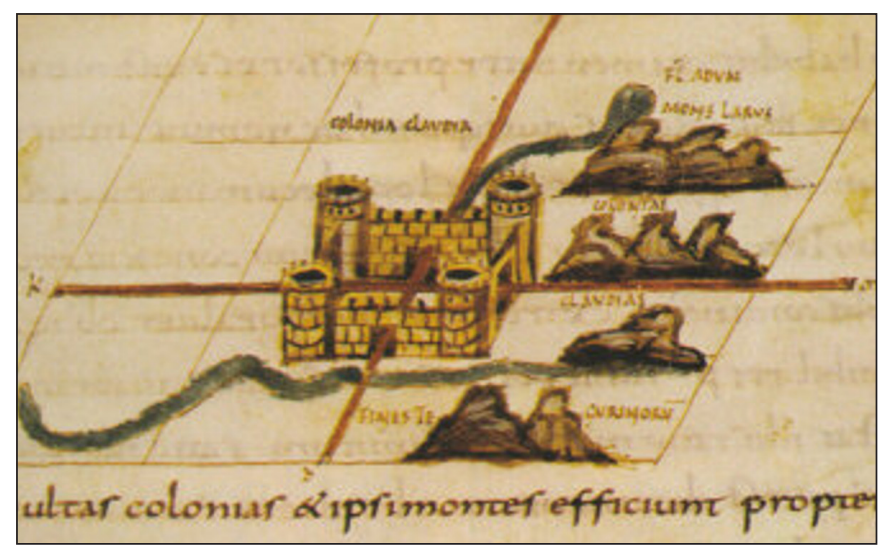

2. kép. A középkori másolatokban megmaradt Corpus Agrimensorum egyik példányának, az ún. Palatinus 1564 manuscript 9. századból származó miniatúrájának centuriatio ábrázolása „Colonia Clavdia” (feltehetően Aventicum) körüli földosztás és a topográfia ábrázolásával 


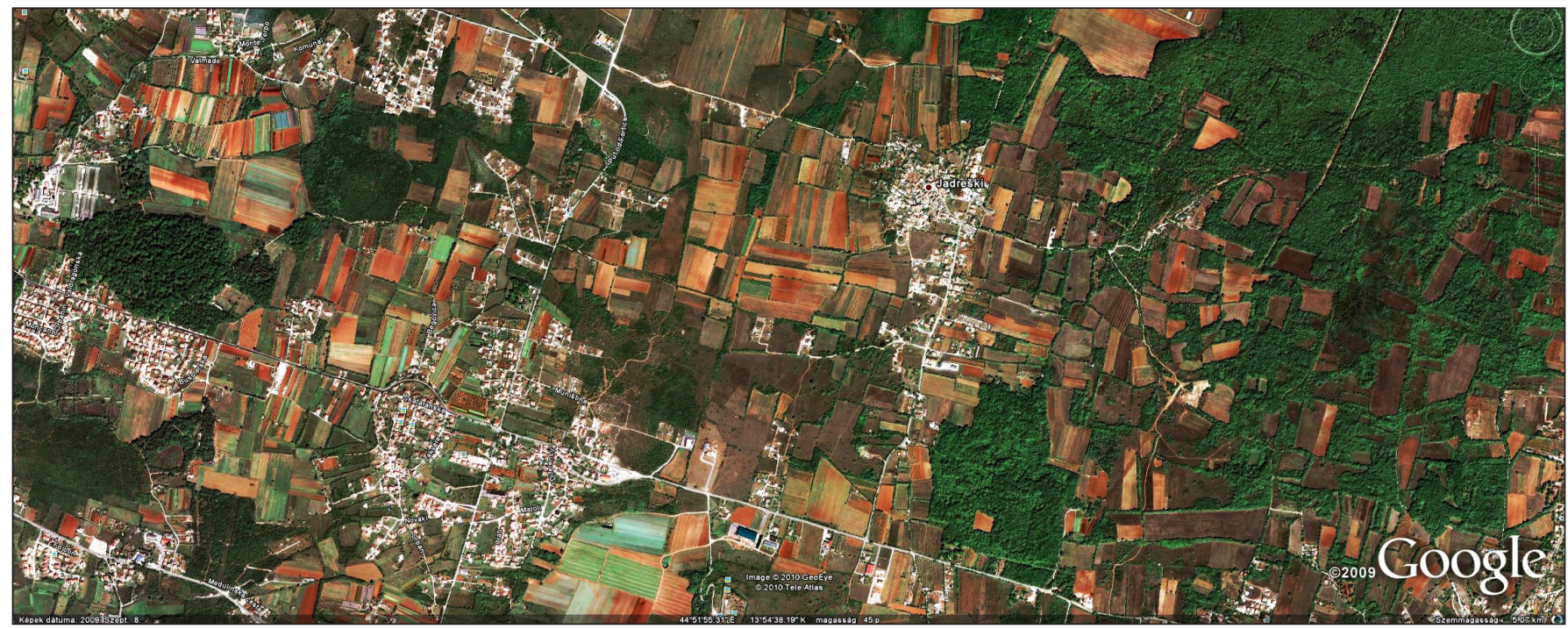

3. kép. A Google Earth-ön keresztül hozzáférhetö müholdfelvétel az isztriai Pula (Colonia Iulia Pola Pollentia) környékéröl. A négyzetes alakzatban futó mai utak $2 \times 2$ centuria egységet $(\mathrm{kb} .1,4 \times 1,4 \mathrm{~km})$ határolnak.

melyek ugyanilyen, egy-egy colonia (némely esetben más) területeken létrehozott „,vidéki” földúthálózat részei voltak.

Miért is említjük a birodalomszerte több helyen megtalált, impozáns távolsági utak megépítésének kérdéséhez a vidéki földútrendszert? Azt már az ókori földmérök is leírják, hogy a kialakítandó földbirtokrendszer, a centuriatio lehetőleg a táj adottságaihoz igazodjon, amelyet meghatározhat tengerpart, öböl, folyó vagy egy fontos út is. Korinthos körül például a hálózatokat a tengerparthoz és egymáshoz képest határozták meg (Romano, 2006). A kutatás számontart a Pó-síkságon, a via Aemilia mentén több, egymáshoz is illeszkedö, de alapjában véve a fóút vonalvezetésén alapuló, ortogonális kialakítású földfelosztást. Itt van például az isztriai Pula környéke is, ahol a szabadon rendelkezésre álló távérzékelési adatok alapján bárki számára feltünhet a mai tájat is uraló derékszögü müvelési rendszer, amelynek a római kori kialakítás az alapja (3. kép).

A tagolt domborzaton, nehezen járható hegyvidéki tájakon valószínüleg a római útépítők is jóval korábbi csapásokat, ösvényeket vagy évszázadok óta használt utakat tettek járhatóbbá, építettek ki korszerübbé, de szelídebb geomorfológiájú területeken szabadon alakíthattak ki új útvonalakat. A Britanniában feltérképezett római utak helyzetét vizsgálva Peterson arra a következtetésre jutott (PETERSON, 2014), hogy azok nyomvonalvezetésében fellelhetők matematikai, (koordináta-)geometriai összefüggések a centuriatio hálózatával. A római földosztás során létrejött centuriatio egy gigantikus koordináta hálózat, amely támpontul, irányzékul szolgálhatott a főbb katonai/kereskedelmi utak kialakításánál is. Ez igazolhatja azon feltételezéseket, mely szerint a topográfia beható tanulmányozása és annak felmérése megtörtént egy terület elfoglalása után. Ha ezt a lehetőséget elfogadjuk, akkor a felszínformákban Britanniához hasonló Pannonia esetében is nagy segítség lehetne ez a szinte bárhol kialakítható utak megtalálásában.

\section{EGY PANNONIAI RÓMAI ÚT ÚJRAÉRTELMEZÉSE}

A Magyarország területén a 18-19. században véghezvitt kataszteri és topográfiai katonai térképezések során a készítők sok esetben rögzítettek római vagy rómainak vélt útnyomokat. Ezen adatok alapján sikerült az 1970-es évek közepén Tóth Endrének felmérni és dokumentálni az egyik leghosszabb magyarországi római útszakaszt Szombathely és Sárvár között (4. kép). Ez a második katonai felmérésen „Alte Römerstrasse" felirattal szereplö út már korábbi kataszteri térképeken is rómaiként volt megjelölve (TóTH, 1977). Néhány helyen régészeti feltárásokkal is sikerült azonosítani ezt az utat a 2000-es évek elején (KISs, 2007; Anderkó, 2009). Tóth Endre az Itinerarium Antoniniana ókori útleírás adatainak megfelelően ezt az utat a Savaria és Brigetio közötti (Itin. Anton 262, 9-263, 2) útszakaszként azonosította, és azóta is ennek megfelelően kezeli a kutatás. 
Bödöcs András • Paradigmaváltás a római utak kutatásában?

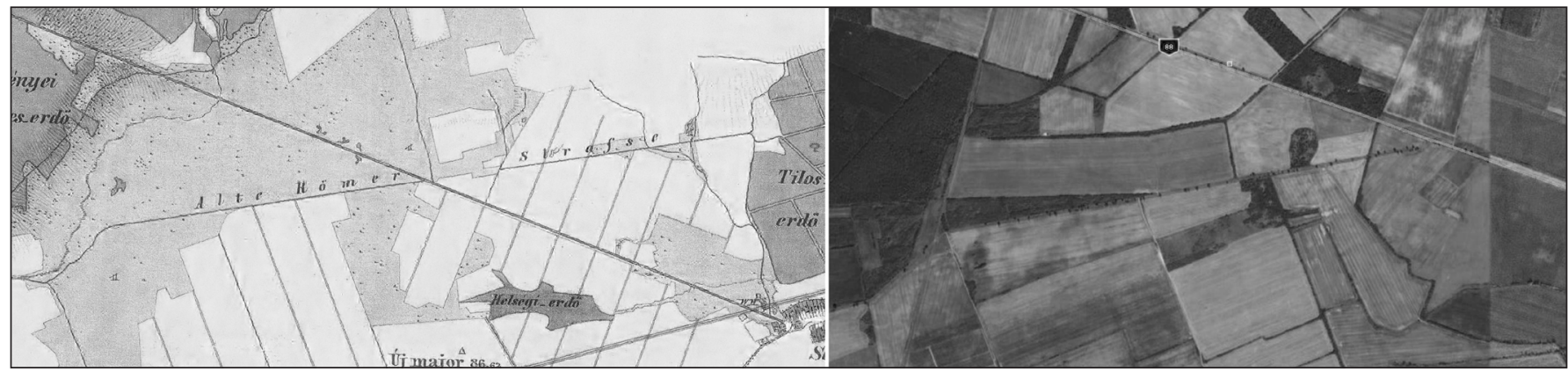

4. kép. A második katonai felmérésen (jobbra) szereplö felirat tanúsága szerint Bögöt határában római út fut. A müholdfelvételen (Google Earth) jól kivehetö az egyenesen futó aszfaltozott út folytatásában haladó útnyom. A terepen sajnos már nem érzékelhetö a kavicsos töltés, mint azt 1977-es publikácójában Tóth Endre (TóTH, 1977) leirta.

Ugyanakkor az archív és recens távérzékelési adatok hozzáférhetőségének, az újabb feltárások eredményeinek és ezen adatok térinformatikai elemzésének eredményeként újabb lehetőség is felmerült e nyomvonal értelmezésében. Az 1990-es évek végétől meginduló, nagy felületü feltárások eredményei több kisebb, római korhoz köthető földútjellegű útszakaszt hoztak napvilágra, amelyeket sikerült egy összefüggő ortogonális rendszerbe integrálni térinformatikai eszközökkel (BöDöcs, 2008; 2014). Kiderült, hogy ezek a földutak egy nagyobb kataszteri rendszer részei, a Savaria alapítása után létrejött centuriatio elemei. A számítógépes modell segítségével megtalált légi régészeti jelenségek, továbbá a régészeti feltárási adatainak sikeres összeillesztése alapján elmondható, hogy Savaria körül olyan földosztási rendszer jött létre, amely paramétereiben minden szempontból megfelel a fentebb említett CAR kora császárkori szerzői által javasolt legtökéletesebb kiépítési struktúrának. E földosztás azonosítására korábban is történtek kísérletek (MócsY, 1965; Gugl, Doneus \& Doneus, 2008), de régészeti igazolásuk elmaradt. Az is kiderült az újabb rekonstrukcióval, hogy szemben azokkal az egykor a Római Birodalomhoz tartozó területekkel, mint például Tunézia, Észak-Itália, de főleg Franciaország, ahol már korábban is sikerült térképészeti és légifotó-szürésekkel (pl. filtrage optique: CHARRAUT \& FAVORY, 1993; GUGL, 2005; BöDÖCS, 2011) ilyen nyomokra akadni, Magyarország jelenlegi topográfiai viszonyai nem kutathatók közvetlenül ilyen módszerekkel nagy hatékonysággal, mert a mai tájkép kevésbé őrizte meg a római beavatkozás nyomait úgy, mint a fent említett területeken. Az utak tájolásának vizsgálata azt mutatja, hogy a római földosztás már nem mutatható ki markánsan a mai tájelemek irányítottságában úgy, ahogy azt a nyugat-európai példák esetében (BöDőcs, 2009). Ugyanakkor

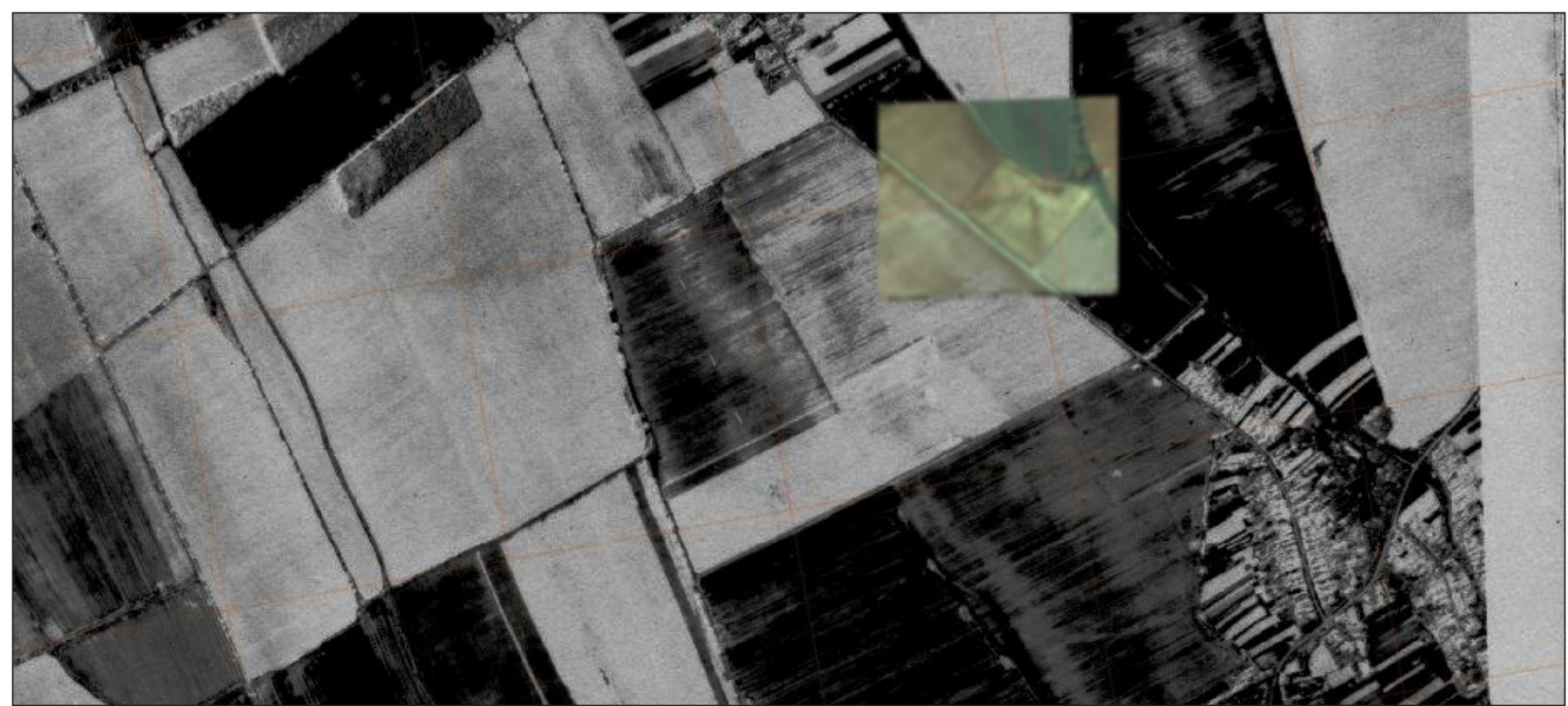

5. kép. Köszegpaty és Vasasszonyfa közötti területen a Hadtörténeti Intézet légifotó-archívumából származó 1986-os felvételen jól látszanak a centuriatio-modellre (halvány vonalak) illeszkedö vonalas jelenségek (sötét sávok), egy komplett centuria. A felvételen az ÉK-i sarka nem látszik ugyan, de azt egy 2003-as Google Earth adatrétegböl ki lehetett egészíteni. 
Bödöcs András • Paradigmaváltás a római utak kutatásában?

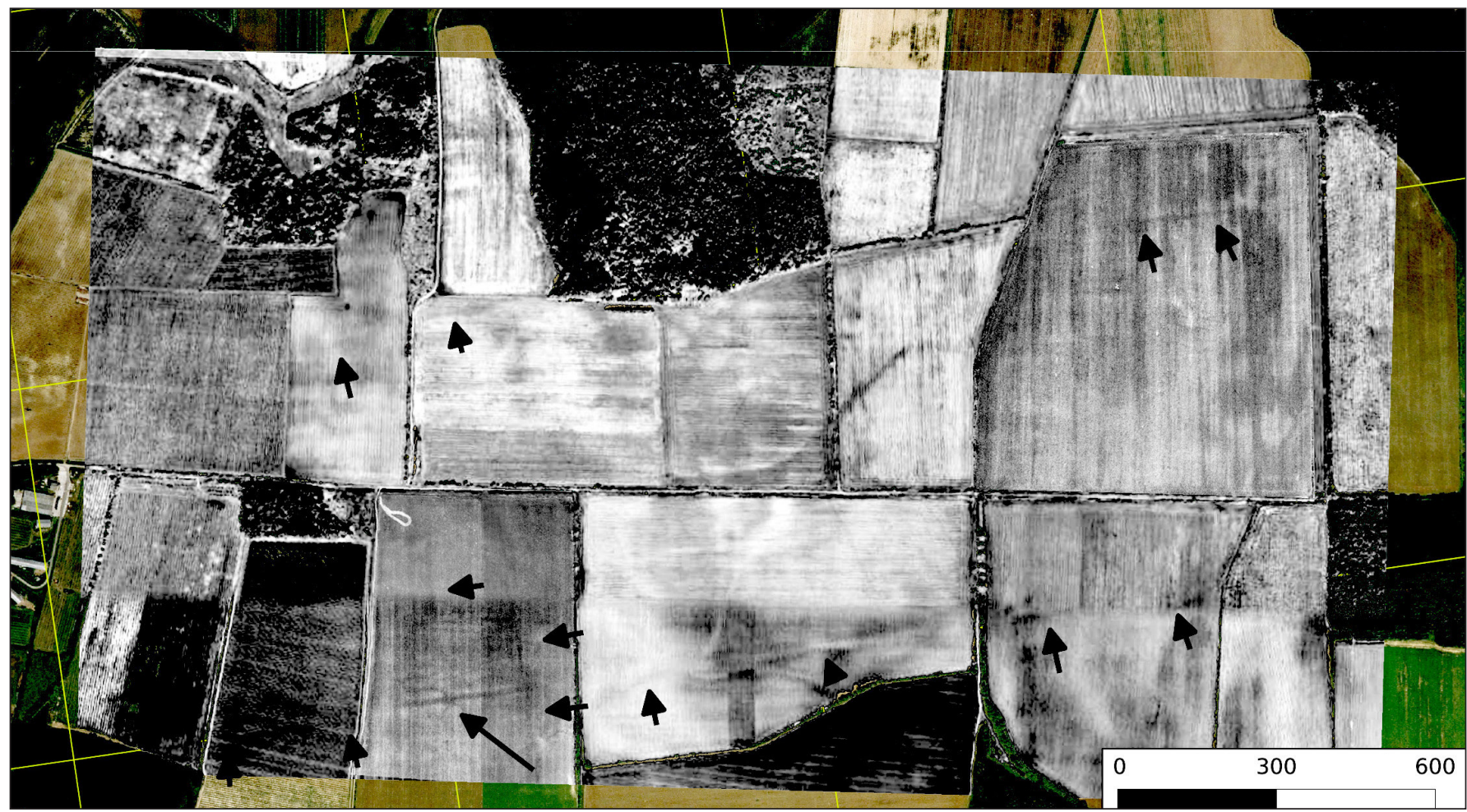

6. kép. Különbözö idöszakokból és forrásokból származó fotómozaik, a fehér segédvonalakkal ábrázolt centuriatio-emodellel. Jól látszik a kép alján húzódó K-Ny irányú út (decumanus maximus), illetve egy centuria távolságra északra húzódó másik út/ ároknyom. A kép bal alsó szélén lévö ferde nyil a geofizikai felmérés helyszinét mutatja.

a régészeti adatok alapján felállított elméleti modell segítségével a távérzékelési adatokból egyre-másra lehetett újabb és újabb részleteket (5. kép) beilleszteni a még hiányos képbe (BöDÖCs, 2008; 2011; 2013; 2014; 2015).

Ebbe a rendszerbe illik a Szombathely és Sárvár közötti római út, illetve ilyen az a - több légifotó alapján összeillesztett - mozaik is, amely Szombathelytől nyugatra Felsőcsatár térségét ábrázolja (BöDŐCs, 2013).

A 6. képen lévő fotómozaikon jól kivehető egy K-Ny-i út markáns vonulata, amelyet néhány helyen keresztez egy-egy merőleges, szintén útnak vélhető jelenség (limes). Különleges jelentőségét az adja ennek az útnak, hogy pontosan a Tóth Endre által publikált Szombathely-Sárvár közötti római út nyílegyenes meghosszabbítása nyugat felé. A felvételek alapján kiválasztottunk egy területet, ahol geofizikai (magnetométeres) felméréssel próbáltuk igazolni, hogy a légi felvételeken látható jelenségek valóban centuriatio-modellként és római birtokhatároló utak és árkok kereszteződéseként értelmezhetőek.

A 7. kép kompozitján jól kivehető a K-Ny irányú úttest, annak árkai, illetve a derékszögű út- és árokkereszteződés, amely az egykori parcellaegységek (centuriae) határait kijelölte. A Felsőcsatár és Sárvár között immár végig feltételezhető római út építéskori, elsődleges funkciója, hogy a Savaria territoriumán létrehozott veteranus-birtokrendszer K-Ny-i fötengelyeként (decumanus maximus) szolgáljon. Felmerül-

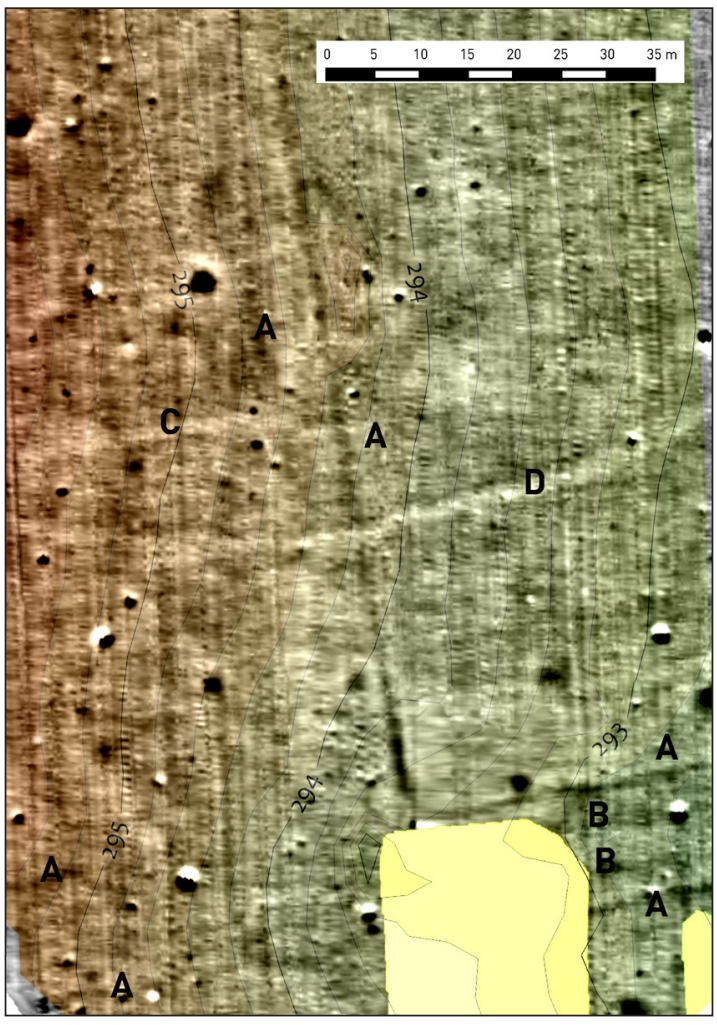

7. kép. A felsöcsatári helyszinen felmért, a modell alapján útkeresztezödésnek feltételezett jelenségek magnetométeres felvételen látható anomáliái. Jól kivehetö a K-Ny út (decumanus maximus) árkai között az úttest (B), illetve a centuriá-k határoló árkai (A). A felmérést Márkus Gábor készítette. 
Bödöcs András • Paradigmaváltás a római utak kutatásában?

het a kérdés, hogy ez már egy létező út lehetett-e a birtokrendszer kialakításakor, amelyre a forrásaink alapján az ortogonális rendszert tájolták, vagy teljesen újonnan, a Kr. u. 1. század közepén létrehozott útról van-e szó? Ismert-e olyan út egyáltalán ebben a régióban ekkor, amit figyelembe vehettek a tájoláskor?

\section{TÁJOLÁS - TERVEZÉS - FELMERÉS}

A decumanus maximus mellett a másik fö tengely, a cardo maximus erre merölegesen haladt, jelen esetben É-D irányban. Ez nyomvonalában többé-kevésbé annak az őskori útnak az iránya, amely a Balti-tenger és az Adria közötti kereskedelmet bonyolította le. A legismertebb nyersanyagcikke, a borostyánkő után Borostyánkő-útként ismerjük. E funkciójában a római kori területfoglalás után természetesen szintén megfelelő minőségü kiépítést kapott, amelynek bizonyos azonosított szakaszait a katonai felmérések térképlapjairól, légi és műholdfelvételekről, valamint ásatási adatokból is ismerjük. Kézenfekvőnek tünik, hogy ebben az évszázadok óta használt kereskedelmi folyosóban húzódott egy út, amely használatban volt akkor is, amikor a Kr. u. 1. században sorra jöttek létre katonai létesítmények és polgári települések. A feltárási adatok alapján az azonban bizonyosnak látszik, hogy maga az akkurátus, a római utakra jellemző sajátosságokkal (töltésszerüen magasított, döngölt kavicsos járófelületü, esetenként vízelvezető árkokkal szegélyezett) történő kiépítés az általunk ismert szakaszokon nem történik meg az Kr. u. 1. század közepe előtt ezen a területen (Mladoniczki \& Sosztarits, 2009; Groh, Sedlmayer \& Zalka, 2013). A Borostyánkő-út folyosójában haladó út mint telepítő tényező azonban ennek ellenére is sokkal valószínübb, mint egy korábbi K-Ny-i úté. Arról nem is beszélve, hogy az általában É-D irányhoz tartó cardo maximus az ókori szerzőknél is kiemelt fontosságú volt a kitüzés során (Hyg. grom. 14.). Azt még jelenleg nem tudjuk azonosítani, hogy a két fö tengely hol is metszette egymást, hol lehetett az ún. locus gromae, a kezdőpont, de a colonia eddig megismert alaprajza alapján ezt talán a nyugati kapun kívül és nem a város központjában kell keresnünk (ld. 9. kép).

Míg a várost északra elhagyó út feltételezett nyomvonala Herény térségében (8. kép) még hosszan a centuriatio egyik földútján (ún. limes actuarius, ill. quintarius) halad, később elkanyarodik tőle, és bár nem a centuriatio tájolásában húzódik, mégis némi összefüggést mutat vele. A Nemescsónál jól megfigyelhető, nyílegyenesen haladó szakasz 1:6, vagy a Frankenau térségében azonosítható vonalvezetés $1: 8$ arányban metszi a centuriá-k, a szabályos négyzeteken alapuló területfelosztási egységek alkotta rasztert (10. kép).

Vajon tényleg tetten érhető az utak építésénél a tudatos tervezés, kijelölés a római földmérők által kitűzött derékszögü koordináta-rendszerben? Arra, hogy ez a fajta földfelosztási rendszer használható információk rögzítésére és tárolására, maguktól a római szerzőktől értesülünk. Nemcsak az egyes centuriá-k területén lévő birtokosok adatait rögzítették, hanem készítettek egy térképet is a területről, amelyen a kataszteri adatokon túl a tájelemeket is ábrázolták. Egy márványtöredékekből összeállítható térkép az ókori Arausio, a mai Orange területéről is elökerült (PIgAniol, 1962). A már megemlített legio III Augusta útépítő és földmérő tevékenységéről több feliratból értesü-

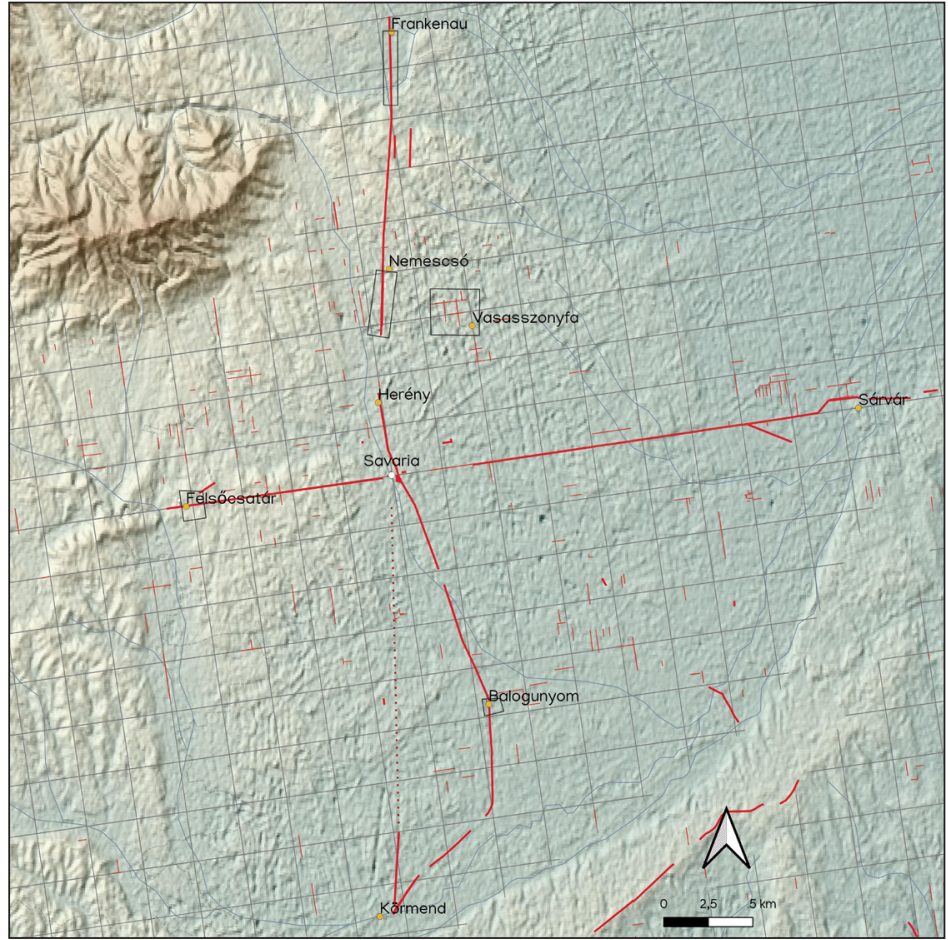

8. kép. Savaria territoriumán futó római utak ismert és feltételezett maradványai (vastag piros), illetve a különbözö légi-

és müholdképek, valamint ásatási adatok alapján feltérképezett centuriatio-nyomok (vékony piros). A területen csak az ún. quintarius (minden 5. centuria határoló) utak lettek feltüntetve (rácsháló). A fekete keretek a 5., 6., 9., 11. képek helyszineit jelölik (szerkesztette Bödöcs A.) 
Bödöcs András • Paradigmaváltás a római utak kutatásában?

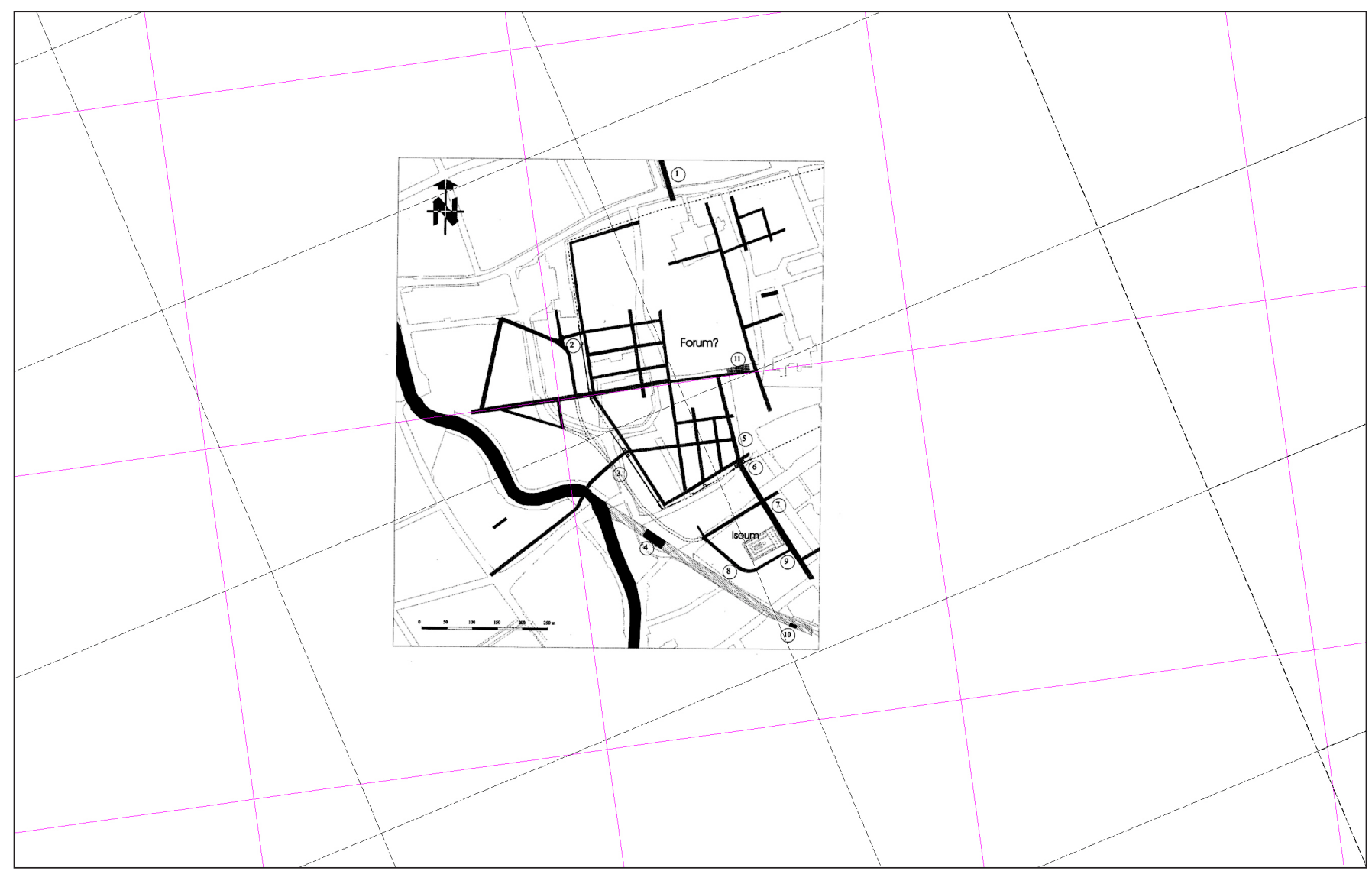

9. kép. Savaria utcarekonstrukciója (Mladoniczki \& Sosztarits 2009 nyomán) és a centuria-hálózat elméleti kialakitása. Savaria esetében nem beszélhetünk a város középen áthaladó (ld. 2. kép) tengelyekröl. Valószínüleg a nyugati kapun kivül kell keresnünk a szimbolikus locus gromae-t, a kezdöpontot. A szabályos négyzetháló mellett, a téglalap alakú rács Mócsy András által feltételezett centuria-rekonstrukció (MócSY, 1965).

lünk egyébként, amelyek rendkívül izgalmas, több tudományágat is érintő szakmatörténeti hírforrásul szolgálnak (AE 1905, 177; CIL VIII, 10018; 10023) vagy Anoninus Pius idejéből a via Septimia (Numidia) építéséről (CIL VIII, 2705), illetve limitatio/centuriatio kiméréséről (AE 1905, 185). Ezekből a feliratokból azt is megtudjuk, hogy hatalmas területeket felmértek derékszögü koordináta-rendszert használva, amelyet szintén térképkészítésre is alkalmaztak (CIL VIII, 22786f). A szövegek a felmérés középpontjától óriási, több száz km-es távolságokat jelölnek. (Decramer 2001; DeCRAmer et al., 2003). Mint láttuk, ilyen térképet aztán egy későbbi határvita alkalmával felhasználtak az újrakitüzés során. Vegetiustól (Veg. mil. 3,6) tudjuk, hogy a katonai parancsnok birtokában volt topográfiai leírásoknak, ugyanis szerinte a hadba induló parancsnokoknak szükségszerüen rendelkezniük kellett a területet pontosan ábrázoló térképpel, amelyek az itinerarium-okhoz hasonlóan információt adtak többek közt szállásokról, vízvételi helyekről, átkelőkről és lóváltó helyekről. Tehát kézenfekvőnek tünik, hogy ha már egy területet ilyen akkurátus ortogonális rendszerben felmérnek a birtokok kialakításakor, és annak egy részéről - a colonia-földekről - biztosan térkép is készül, akkor ezt miért ne használják fel a provincia teljes feltérképezéséhez. Emellett Pannoniában a források szerint amúgy sem csak colonia-földeket mértek fel a centuriatio-nál használt módszerekkel, így joggal feltételezhető, hogy rendelkezésre állt egy viszonylag pontos, még térképi koordinátákkal is rendelkező összeírás a provincia topográfiájáról az észak-afrikai felmérésekhez hasonlóan. A kitüzött négyzethálós földfelosztást az útkijelölésnél, nyomvonaltervezésénél felhasználhatták. Bizonyos irányszögeket így könnyen kimértek. Nem volt szükség bonyolult mérőeszközökre, mint például dioptra-ra, a mai teodolitok ösének nyilvánított eszközre ahhoz, hogy különböző szögvariánsokat tudjanak kitűzni (pl. közelítőleg $45^{\circ}$ $\left.1: 1 ; 30^{\circ}-4: 7 ; 10^{\circ}-1: 6 ; 7^{\circ}-1: 8\right)$. A cikk elején említett, Hugh Davies által feltételezett topográfiai ismeret és térképezési tapasztalat megvolt ahhoz, hogy tudatos nyomvonalvezetéssel lássák el az utakat. Vitruvius (Vitr. 9, 7, 1) leírásában a gnomon, a földrajzi fokhálózat meghatározáshoz is használatos eszköz sem szög- 
Bödöcs András • Paradigmaváltás a római utak kutatásában?

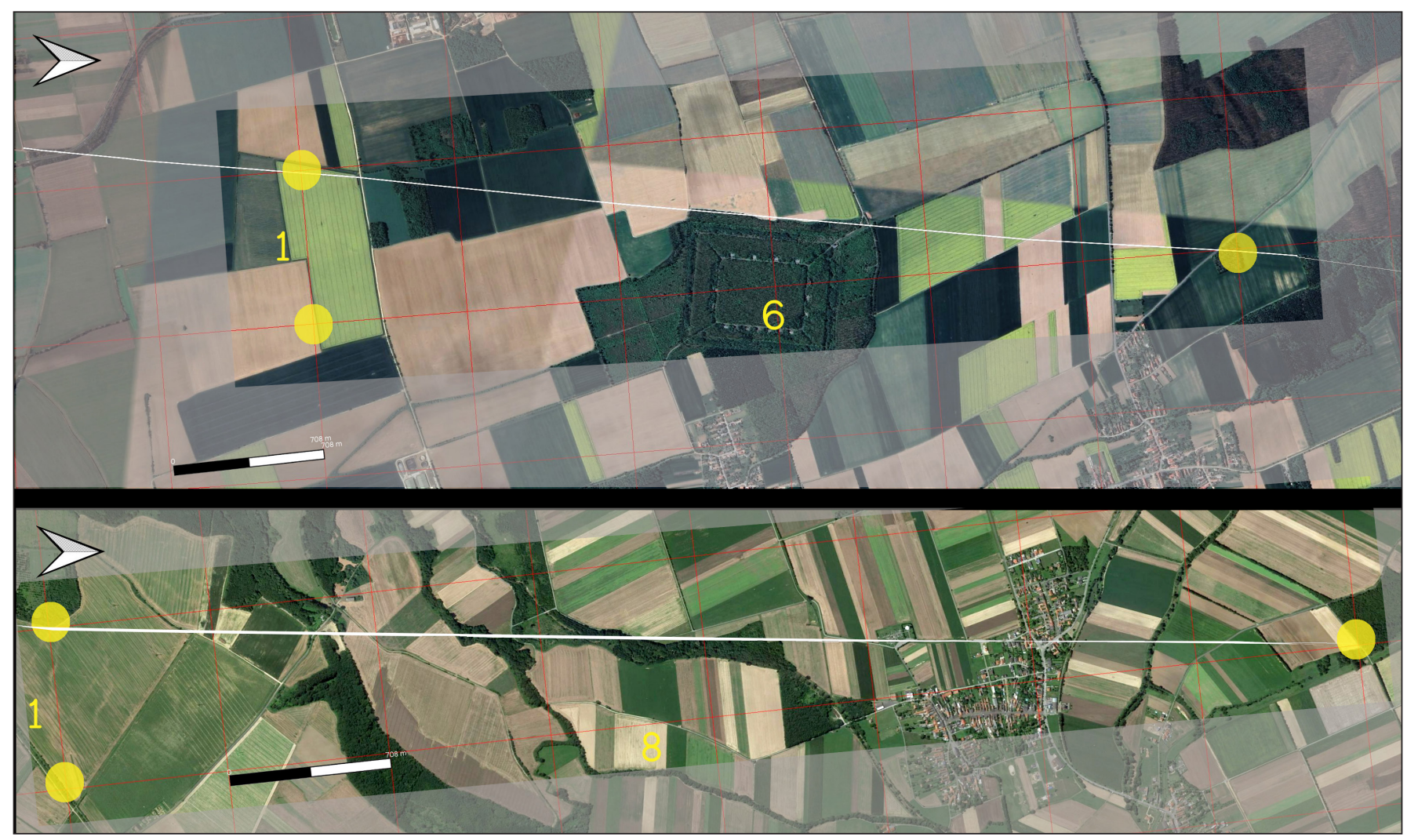

10. kép. A Borostyánkö-út légi- és müholdfelvételekröl (Google Earth) azonositható szakaszai Nemescsó (fent) és Frankenau (alul) térségében. A nyomvonal (fehér) és a centuria-rács (piros) aránya 1:6, illetve 1:8. (szerkesztette Bödöcs A.)

értékekkel, hanem a gnomon pálcájának és annak árnyékának egymáshoz viszonyított arányaival fejezi ki a földrajzi szélességi fok értékét. A meghatározásai (pl. Alexandria esetében az arány 5:3, Rhodosz esetében 7:5) nagyjából jó közelítést is adnak a földrajzi szélességröl. Az arányokkal történő leírás, azok használata tehát nem állt messze az ókori római mérnöki gyakorlattól.

\section{A LELŐHELY-DIAGNOSZTIKA LEHETŐSÉGEI AZ ÚTKUTATÁSBAN}

Hol segít ez tehát a római utak feltérképezésében? Ma nemcsak a hagyományos felszíni topográfiai kutatások (pl. terepbejárás) alapján próbálja a régészet a lelőhelyek lehetséges helyzetét valószínűsíteni. Egyre többször sikerül modellezési eljárások segítségével leszükíteni azt a területet, ahol aztán célzottan különféle lelöhely-diagnosztikai eszközökkel érdemes tovább vizsgálódni. A légi régészeti kutatások továbbra is fontos szerepet játszanak az utak kutatásában, bár ezen belül a rendszeres monitorozó, pilóta nélküli eszközökkel (UAV/RPAS), közkeletübb elnevezésükkel drónokkal végrehajtott repülésekkel a látható és infra tartományú felmérések tekintetében újabb eredmények várhatók. Az összefüggő nagy felületeken alkalmazott geofizikai felmérések számos esetben hoztak meglepetésszerü eredményeket. Már szó esett a birtokfelosztás-modell ellenőrző méréseiröl, azonban a korábbi felmérések újraértékelését is érdemes elvégezni, mint pl. a Nemescsó és Balogunyom térségében ismert útállomások vizsgálati eredményeinek esetében. A Balogunyom-Ceteháza lelőhelyen az ismert útállomás magnetométeres felmérésének eredményét a földosztásmodellel összehasonlítva érdekes eredményt kapunk (11. kép).

Maga az útállomás a feltárási bolygatás miatt nem látható a felmérés eredményén, helyét a kép közepén kivehető intenzív anomáliák által jelölt területen lehet azonosítani. Érdekes azonban, hogy a Borostyánkőút feltételezett nyomvonalán olyan árkok láthatók, amelyek iránya és helyzete megfelel a centuriatio felosztásának (11. kép: sárga nyilak), ráadásul egy feltételezett parcellahatároló útkereszteződésnek megfelelő módon (K-Ny irányú árkok) derékszögben metszik is egymást ott, ahol a pontozott vonallal jelölt modell azt feltételezi. A magnetométeres felmérésen egyelőre nem kivehető egy jól kialakított római úttest (Borostyánút) nyomvonala, aminek lehet az egyik oka, hogy valóban a mai mủút alatt húzódik az egykori római 
Bödőcs András • Paradigmaváltás a római utak kutatásában?

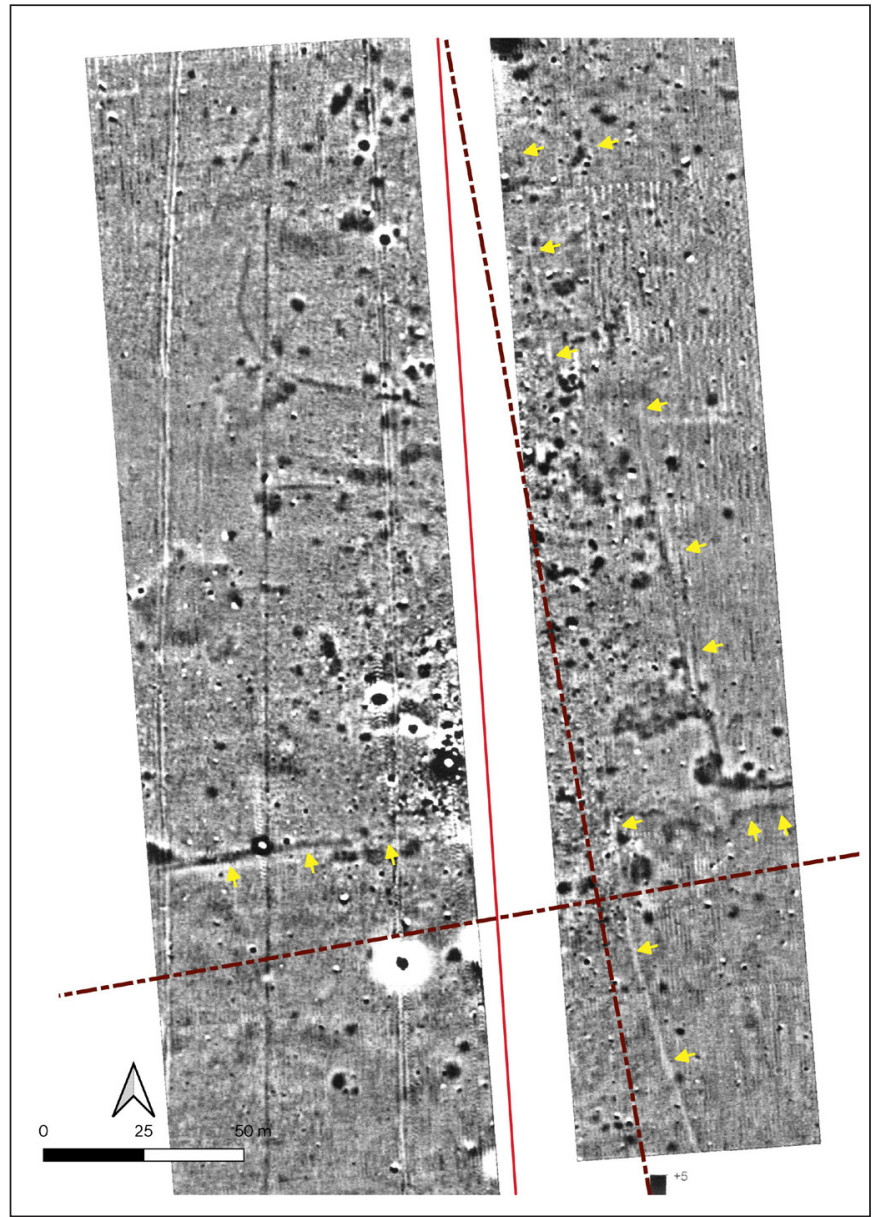

11. kép. Balogunyom-Római útállomás körül az ÖAI és a Savaria Múzeum együttmüködésében felmért terület magnetométeres képe (GROH, SEDLMAYER \& ZALKA 2013 nyomán). Középen a fehér csík a mai müút, amely alatt halad a feltételezett római nyomvonal. A szaggatott vonalak a centuriatio elvi kialakitása. A sárga nyilak jelölik a centuriativo-val megegyezö tájolású árkokat (szerkesztette Bödöcs A.).

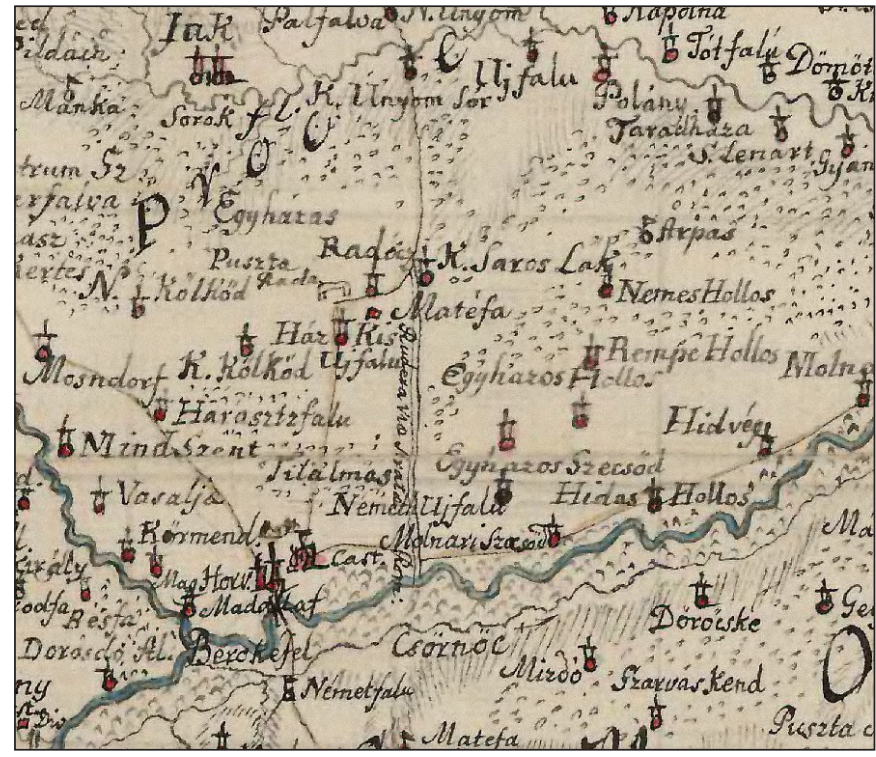

12. kép. Az OSZK TK 1068 jelzetü, Vas vármegyét ábrázoló térképének részlete a római utat jelölö „, Rudera via strata Rom." felirattal.

út. Az azonban bizonyos, hogy az ismert útállomás közelében kimutathatók a római birtokfelosztás elemei, így az épület és centuriatio közötti összefüggés kérdését is érdemes lenne tisztázni.

Egy 18. századi térképlapon (TóTH, 2005; OSZK TK 1068; 12. kép) egy Körmendtől északra tartó római útnak jelölt nyomvonalat találunk. Sajnos a térkép egész Vas vármegyét ábrázolja, és nem is akkurátusan elkészített katonai topográfiai térkép, hogy a rajta lévő adatot megfelelő módon fel lehessen dolgozni. Bár teljesen pontosan - ahogy például a második katonai felmérésen ábrázolt út - nem lokalizálható, hozzávetőlegesen rekonstruálni lehet az irányát, amely utalhat akár hadi útra, de ugyanúgy egy centuriá-t határoló útra is. Ezt a szakaszt az összesító térképen (8. kép) pontozott vonallal hosszabbítottuk meg Savaria irányába. A felvetett tervezési stratégiai lehetőségek - így a centuriatio vonatkoztatási rendszerének kihasználása az útépítéshez - alátámaszthatja azt az elképzelést, hogy egy olyan útról van szó, amelyik jobban beleillik a Nemescsó, illetve Frankenau térségében kimutatható római út tervezési koncepciójába. Az ilyen modellekkel összevethető történeti adatok segíthetnek egy szükebb kutatási terület kiválasztásában, hogy a lelőhely-diagnosztikai eszközök segítségével konkrétabban meghatározott földterületeken lehessen tesztkutatásokat végezni.

\section{EPILÓGUS}

Összességében elmondható, hogy a nyugat-magyarországi régióban összefüggés mutatható ki a római útvonalak és a földfelosztás geometriai elemei között. Ennek következtében joggal feltételezhető, hogy olyan tervezési stratégia állt az útépítések mögött, amely a célállomások helyének ismeretében a közöttük lévő irányt tartani, illetve korrigálni tudta a terepalakulatok figyelembevételével (pl. folyógázlók). A további megfigyelésekhez azonban mindenképpen szükséges, hogy immár nagy pontosságú helymeghatározással térképezzük fel a meglévő és azonosítható nyomokat, illetve nagyobb tesztfelületeken nyíljon lehetőség az egyes modellezési eredmények ellenőrzésére. Így a nyugat-magyarországi régió biztosabban azonosítható területeiröl fokozatosan az ismeretlenebb belső területek felé terjedhetne a további kutatás. 
Bödöcs András • Paradigmaváltás a római utak kutatásában?

FELHASZNÁLT IRODALOM

Rövidítések

AE Année Epigraphique

CIL Corpus Inscriptionum Latinarum

Anderkó, K. (2009). Mit adtak nekünk a rómaiak? Utakat. https://sirasok.blog.hu/2009/02/02/mit_adtak nekunk_a_romaiak_2 (Letöltés: 2020.08.31)

Bödőcs, A. (2008). A római kori úthálózat térinformatikai vizsgálata a mai Magyarország területén. Doktori disszertáció, Budapest, ELTE.

Bödőcs, A. (2009). A római kori Savaria környéki centuriatio területének vizsgálata térinformatikai eszközökkel. Szakdolgozat, Budapest, BMGE.

Bödőcs, A. (2011). Aerial archaeological substantiation of a Roman cadastre system's predictive model. The Newsletter of the Aerial Archaeology Research Group 42, 13-25. http://www.univie.ac.at/aarg/php/ cms/AARG-News/aarg-news-42 (Letöltés: 2020.08.31)

Bödöcs, A. (2013). Borders: The problems of the aerial archaeological reserach of a Roman limitatio in Pannonia. In: Czajlik, Z. - Bödőcs, A. (szerk.), Aerial archaeology and remote sensing from the Baltic to the Adriatic: selected papers of the Annual Conference of the Aerial Archaeology Research Group, Budapest, 13th-15th September 2012 Budapest, Magyarország (pp. 59-66). Budapest: L'Harmattan Kiadó - ELTE BTK Régészettudományi Intézet.

Bödőcs, A. (2014). Földmérők Savariában. Javaslat a savariai centuriatio újabb elméleti modelljére. In: Balázs, P. (szerk.), Firkák III: Fiatal Római Koros Kutatók III. konferenciakötet (pp.361-372). Szombathely: Savaria Múzeum.

Bödőcs, A. (2015). Neuer interpretationsversuch eines altarsteinfragments aus Savaria. In: Borhy, L. Tankó, K. - Dévai, K. (szerk.), Studia Archaeologica Nicolae Szabó LXXV Annos Nato dedicata (pp. 4556). Budapest, L’Harmattan Kiadó.

CIL. Corpus Inscriptionum Latinarum

Chevallier, R. (1997). Les Voies Romaines. Paris.

Cserményi, V. \& Tóth, E. (1979-1980). Eine römische Straßenstation und die Straßenstrecke zwischen Salla und Arrabona. Savaria 13-14, 171-203.

Davies, H. (2002). Roads in Roman Britain. Gloucestershire.

Decramer, L. R. (2001). Auf den Spuren der Geometer der Dritten Legion Augusta. Römische Landvermessungin Nordafrika. Der Vermessungingenieur 3, 194-201.

Decramer, L. R., Hilton, R., Martin, A. \& Plas, A. (2003). Centuriations et orientation solaire. Les bornes gromatiques de Tunisie. Communication à la Table ronde du Cercam.

Charraut, D. \& Favory, F. (1993). De la carte topographique à l'analyse d'images: Méthodologie de 
Bödöcs András • Paradigmaváltás a római utak kutatásában?

l'identification des limitations antiques. Cadastres et occupation dusol. Revue Archéologique de Narbonnaise 26, 19-56.

Finály, G. (1903). Római utak a Dunántúlon. Archaeológiai Értesitő 23, 164-173.

Glynn-Jones, A. (1996). Holding Up a Mirror: How Civilizations Decline. London.

Groh, S., Sedlmayer, H. \& Zalka V. Cs. (2013). Die Straßenstationen von Nemescsó und Sorokpolány an der Bernsteinstraße (Pannonia, Ungarn). Grabungen, geophysikalische Prospektionen und Surveys 19801982 und 2009-2012. Wien.

Gugl, Ch. (2005). Limitatio Carnuntina. GIS-Analyse der römischen Zenturiation im Raum Carnuntum (Niederösterreich). Anzeiger der Österreichischen Akademie der Wissenschaften 140 (1), 61-126.

Gugl, Ch., Doneus, M. \& Doneus, N. (2008). Roman field boundaries in West Pannonia - diversity of a system. In: Compatangelo-Soussignan, R. - Bertrand, J.-R. - Chapman, J. - Laffont, P.-Y. (Hrsg.), Marqueurs des paysages et systèmes socio-économiques. Proceedings of Le Mans COST Conference, Documents Archéologiques 1 (pp. 113-125). Rennes.

Grüll, T. (2008). A principátus geopolitikai propagandája. Ókor VII (3), 56-65.

von Hagen, J. (1967). Römerstraßen der Rheinprovinz. Erläuterungen zum Geschichtlichen Atlas der Rheinprovinz VIII. Bonn.

Kiss, P. (2007). Temető a Savaria-Arrabona út mentén (Sárvár, Sár). Előzetes beszámoló. - Bíró, Sz. (szerk.), FiRKák I. Fiatal Római Koros Kutatók I. Konferenciakötete (pp. 267-282). Győr.

Mladoniczki, R. \& Sosztarits, O. (2009). Die Strecke der Bersteinstraße in Savaria. In: Bíró, Sz. (Hrsg.), Ex officina... Studia in honorem Dénes Gabler (pp. 325-356). Győr.

Mócsy, A. (1965). Savaria utcarendszerének rekonstrukciójához. Archaeológiai Értesitő 92, 27-36.

Moreno Gallo, I. (2004). Vias Romanas. Ingenería y técninca constructiva. Monterreina.

Peterson, J. (2014). Roman roads and surveying. East Herts Archaeological Society Newletter 35.

Piganiol, A. (1962). Les documents cadastraux de la colonie romaine d'Orange. Gallia, suppl. XVI. Paris.

Romano, D. G. (2006). Roman Surveyors in Corinth. Proceedings of the American Philosophical Society $150,62-85$.

Rómer, F. (1866). Mürégészeti kalauz különös tekintettel Magyarországra. Pest.

Tóth, E. (1975). Pannonia római útvonalainak a kutatása. Somogyi Közlemények 2, 275-278.

Tóth, E. (1977). A Savaria-Bassiana útszakasz. Archaeológiai Értesítő 104, 65-77.

Tóth, E. (2005). Római utak a Dunántúlon. Müemlékvédelem XLIX (1), 1-8. 
Bödőcs András • Paradigmaváltás a római utak kutatásában?

Ürögdi, Gy. (1979). Hogyan utaztak a régi rómaiak. Budapest.

Smith, W. (1875). A Dictionary of Greek and Roman Antiquities. London.

Visy, Zs. (1978). Pannoniai limes-szakaszok légi fényképen. Archaeológiai Értesitő 106, 235-259.

Visy, Zs. (1980). Római jelzőtornyok és a limes-út Intercisa térségében. Archaeológiai Értesitő 107, 166-175. 